\title{
The inner librarian
}

\section{Achieving your professional goals by following your inner voice}

ike everyone else, librarians often fall

—into the trap of an over-committed work life, and sometimes struggle with finding the time and energy for professional development. Here, I'll share a more intuitive way of approaching your own professional development, by following your inner voice and finding balance by disconnecting. This unique approach can energize both your professional and personal lives.

\section{Follow your inner voice}

You may ask, what do I mean by the "inner voice"? It's the speaking of your innermost desires, though it's often ignored because it doesn't fit your own conception of yourself. Think of inspiring figures like Martin Luther King Jr. or Florence Nightingale- - they surely followed an inner voice to achieve great things.

Finding your own inner voice begins with reflection. You need time to step away from things to see where you've been, where you are, and where you're going. When you find time for reflection, you begin to see the "meaningful coincidences" and synchronicities that you've experienced, such as finding a great new job after being let go from the last one (which wasn't a good fit for you anyway).

As you begin to reflect, you see how your inner voice has helped you through difficult situations. For example, as I was beginning to explore librarianship as a career, I also followed a dream of mine to play music. Quite out of character, I auditioned as a drummer in a local rock band. That audition changed my life in several ways. At the same time, the wife of the bass guitar player introduced me to librarianship. She told me about the highly regarded MLIS program she was attending, that used a ground-breaking online/lowresidency approach. This was exactly what I was looking for: a professional degree in an area that I had an aptitude for, and one which wouldn't uproot my life, just when it was blossoming with musical passion. Against the odds, I applied to the program, got in, and after two years of stimulating personal growth, I was a newly minted librarian.

Listening to my inner voice guided me to music as not just a hobby, but as an integral part of my professional life. Looking back, I never imagined that I would be able to bring drumming into my professional development agenda. Yet, drumming as a tool for organizational development is the focus of professional research, and also turned into a published article. I've been able to do team building sessions with library staff, students, and faculty. "Following your muse" can make the professional development process more intuitive and enjoyable.

Here are some tips on following your inner voice:

- Look for "meaningful coincidences" (synchronicities) happening around you; you'll begin to see the connections between events that seem unrelated.

- Keep a journal of the hopes, frustrations, and milestones in your life.

Pete McDonnell is systems/distance learning/ circulation librarian at Bemidji State University, e-mail: pmcdonnell@bemidjistate.edu

(c) 2012 Pete McDonnell 
- Build in time for contemplation and reflection.

\section{Find balance by disconnecting}

Though disconnecting from the busy information world every once in a while may strike some librarians as anathema to the bread-andbutter work of libraries, this shouldn't come as a shock. Libraries enjoy a long history of being refuges from the busy outer world.

Libraries can be islands of solitude in this hyperconnected world, and books afford their readers the unique opportunity to be alone in the quiet study of a single, coherent text. The contrast between reading Web pages on the Internet and the pages of a book is quite clear. As William Powers notes in his book Hamlet's BlackBerry, one of the unique features of book reading is the narrowing of the focus away from outer stimuli, and into the focused train of thought required to follow a discrete narrative. ${ }^{1}$ Similarly, in his book The Shallows, author Nicholas Carr points out that reading Web pages and surfing for information taxes the brain's decision-making abilities more than book reading does, which can leave the reader overloaded. However, reading static texts allows one to go into deeper states of concentration, into almost a meditative state. Where the Web demands constant attention to stimuli, books create a more receptive state of mind, one in which thoughts and information can be allowed to "steep" before being acted upon. ${ }^{2}$

Exploring the natural world-surrounded by the elements, the weather, and various fellow-creatures-also affords opportunities for discovering the power of disconnecting. For example, a good friend of mine is planning to hike a portion of the Appalachian Trail. Though he won't have instant Internet access at his fingertips, he'll be far from disconnected from the world. He'll actually be immersed in a world of information coming from the natural environment around him, such as the changing moods of the weather and the conditions of the trail ahead. On the trail, he'll have to rely on his senses to get around safely and to find a suitable camp. The hike will be a test of his backpacking ability, and it will also surely give more balance to his life, as he "unplugs" from the busy world.

Here are some more ways to disconnect:

- Leave your cell phone at home for a day.

- Take an "Internet Sabbath": disconnect your Internet-connected devices for a weekend.

- Take a walk outside.

- Paint, draw, or play a musical instrument (by yourself or with others).

- Spend time with your favorite pet; research shows that spending time with animals can have a positive impact on your well-being.

\section{Conclusion}

Living an authentic life involves balancing your professional and personal life, so that one doesn't dominate the other. I've found that listening to my inner voice and disconnecting every once in a while has helped my professional life grow in unexpected ways. However, what works for me, may not work for you. So, take a deep breath, turn off the computer, follow your hunches, and walk out that door.

\section{Notes}

1. William Powers, Hamlet's Blackberry: $A$ Practical Philosophy for Building a Good Life in the Digital Age (New York: Harper, 2010).

2. Nicholas G Carr, The Shallows: What the Internet Is Doing to Our Brains (New York: W.W. Norton, 2010).

("Synergism . . ." continued from page 661)

11. M. Garcia, "Teenage Alcohol Abuse," slideshare.net/thl_pihi/teenage-alcohol -abuse.

12. A. Mayne and Y. Chang, "Depression Among LGBT Teens," PowerPoint, www. slideshare.net/thl_pihi/depression-among -lgbt-teens.

13. A. Ziff, "Obstetric Fistula in Developing Countries, www.slideshare.net/thl_pihi /obstetric-fistula. z 